\title{
The Effect of Regent Leadership Style on Motivation, Village Prosperity and Headman Performance in Increasing Society Social Welfare (A Study in Headman Office at Bekasi Regency, West Java, Indonesia)
}

\author{
Suroyo*, Armanu Thoyib**, Surachman**, Margono Setiawan** \\ Management Doctorate Program of Economics and Business Faculty Brawijaya University \\ Malang, East java, Indonesia
}

\begin{abstract}
In improving the community welfare, the good performance of village head was needed, but in reality the performance of village heads in Bekasi regency had not maximized yet. The purpose of this study was to describe the extent of regent leadership style as a leader of village chief in motivating, empowering the performance of the village chief. The method used in this study was a quantitative approach. Data were collected by using a research instrument in the form of a questionnaire given to 127 respondents. Data analysis techniques used in this study was Structural Equation Modeling (SEM) with the help of Amos program. The results showed that the district's leadership style was significantly influence motivation, but motivation did not affect the performance of the village chief. Motivation could not be called a mediator because the district's leadership style directly having significant effect on the performance of the village head, while district leadership style had no effect on prosperity, but prosperity was significantly having effect on the performance of the village head. So, then prosperity also could not be called a mediator. The implication of this study was the regent leadership style was important because it had managed to improve the performance of the village head.
\end{abstract}

Keywords: Regent Leadership Style, motivation, prosperity, and village chief performance.

\section{Introduction}

The improvement of social welfare in the village is the duty and responsibility of village chief. Duties and responsibilities are stipulated in Law No. 11 Year 2009 on social welfare, including social rehabilitation, social security, social empowerment, and social protection. One phenomenon that became an issue in Bekasi district is the village head performance that had not been improved yet. Society expects to be able to empower the change of better life, but the fact that it is still cannot meet the expectations of society. Village head is spearheading of regent which is in underlined forefront in improving social welfare. The previous research has shown that transformational leadership produces motivation and better performance of employees (1), [2] transformational leadership style has to do with motivation [3]. Ozaralli [4] Avolio, et al., [5] said that leadership style has to do with prosperity. Bass [6] describes the transformational leadership style can improve performance. There have been many studies which were linking variable leadership style, motivation, prosperity and performance, but the results are very diverse. Some state that leadership style had no effect on performance [7], there is also mention of leadership styles affect the performance [8], [9]. It is also happen to the leadership style that did not have relation to the prosperity. Men LR [10] describes the leadership style have to do with prosperity. However Sundong [11] claimed leadership style had no effect on prosperity. The different result of previous research and the village chief performance phenomena in Bekasi has been stated to be a background for further research. The purpose of this study is to analyze and explain the direct and indirect effects between regent's leadership styles on motivation, leadership styles to prosperity, leadership style on the performance of village chief, motivation to prosperity, motivation to village chief performance. The prosperity of village chief performance.

\subsection{Leadership Style}

\section{Review Of Related Literature}

Yukl, (12) explained that leadership is the use of influence in the organization or organization situation, which produces something meaningful and direct impact on the achievement of challenging objectives. Kreitner and Kinicki (13) state that leadership is the process of an individual to influence others to achieve a common goal. Leadership can be defined as the use of power and influence to direct the activities of followers toward goal achievement [14]. While Gibson [15] said that leadership is an attempt to use influence to motivate individuals to achieve a goal. 


\subsection{Motivation}

Daft [16] explains that motivation refers to internal and external forces to the person who raises the spirit and perseverance to pursue a series of specific actions. Motivation illustrates psychological process that causes the perseverance to achieve organizational goals [17]. Motivation is a series of processes consisting of three parts that cannot be separated from one another. The first part is something that moves or pushes (arises) someone to do something. The drive usually is a requirement. The second part of the motivation is the direction (direction). There are various roads that can be used to meet the needs of the various alternatives and the person has to decide which path will be used to meet their needs. The last part of the motivation is to maintain (maintenance). The chosen path must be maintained until the requirement is reached [18]

\subsection{Prosperity}

Prosperity can be beneficial to the achievement of predetermined objectives. However, some things to look out for, such as: leader who is fear of losing power, control and authority;. Subordinates who cannot make responsible decisions; Empower subordinates tried before and failed time; shared information can divulge ideas, plans and knowledge to competitors; not everyone wants to be empowered [19].

\subsection{Village Chief Performance}

Byars \& Rue explained that performance refers to the stage of task completion that constitutes the work of an employee. The performance is the achievement of organizational goals by using resources efficiently and effectively (20). Someone's performance would have to be connected to the tasks that become obligations. Therefore, performance refers to behaviors that focus on the goals under the control of individuals who support the goals of organization [21]. Performance can be realized in the form of behavior, both mental and physical, that individuals show in pursuit of organizational goals [22] According to Drucker [23], there are 5 (five) dimensions of performance, such as "the physiological, the psychological, the social, the economic, and the power dimensions.

\subsection{Research approach}

\section{Research Method}

This study is categorized as explanatory research; it is research that aims to explain the causal relationship between the variables through hypothesis testing. The approach of this research is survey approach. The paradigm underlying research paradigm shaped track, with a statistical analysis technique called Structural Equation Modeling (SEM). According to Hair, et al., (24) says that it is possible to be done by using SEM analysis of a series of connections simultaneously, thus providing statistical efficiency.

\subsection{Research Sites}

The study was conducted in rural areas in Bekasi regency, where the object of study is the village head. The choice of location is based on some considerations; the topic is quite unique and interesting to be explored when it is viewed from the aspect of public management / administration management of the village.

\subsection{Population and Sampling Techniques}

Population is the whole object of research being studied. The populations in this study are the village chief in Bekasi. The numbers of villages in Bekasi are around 187, so that the populations in this study were 187 village heads. The samples were partially or representative of the population being studied. The considerations of sampling are the researcher can draw conclusions. For the measurement of the sample is calculated by using the formula of Slovin totalled of 127 head of village.

\subsection{Data Analysis Techniques}

This study uses a quantitative approach by data analysis technique used is Structural Equation Modeling (SEM) with the help of AMOS program.

\subsection{Overview of Respondents}

\section{Research Result}

Bekasi regency was established by Law. 14 Year 1950 on Basics Establishment Environmental District in West Java and in August 15, 1950 set as the birth of the Bekasi Regency. The north border is bordered by Java Sea, west border is Bekasi City and Jakarta, in south is bordered by the Bogor regency, and the eastern border with Karawang regency.

The validity test of the instrument items for Leadership Style variable (X1), Work Motivation (Y1), 
prosperity (Y2), and the performance of the Village Head (Y3), the entire instrument has a value of $r>0.3$ so that it can be stated that all research instruments used is valid. The reliability test of all instruments of Leadership Style variable (X1), Work Motivation (Y1), prosperity (Y2), and the Village Head Performance (Y3) each had alpha cronbach values above0.6 so it is said that all variables are reliable so to do further testing. Characteristics of the respondents in this study were classified based on age, experience, and education obtained through a questionnaire.

Based on the characteristics of age, respondents in this research were 137 people consisting of: age $<40$ years (38 people or 29.9\%), aged $41-50$ years (46 people or $36.2 \%$ ), and age> 50 years (43 people or $33.9 \%$ ). Based on his experience, it appears that the majority of respondents were examined in this study have between 11-20 years experience as many as 41 people or $23.3 \%$, as many as 38 people or $29.9 \%$ had experienced for 6-10 years, 27 people or $21.3 \%$ experienced during the 1 - 5 years while the remaining 21 people or $16.5 \%$ having experience for more than 20 years. Based on the region characteristics, the majority of respondents in this research are scattered in the middle of the Bekasi area with a number of respondent's as many as 43 people or $33.9 \%$,

\subsection{Hypothesis Testing Results}

Hypothesis testing is done by t test ( $\mathrm{t}$ test) at each track direct and indirect effects.

Table 1. Direct Effect Hypothesis Testing Results

\begin{tabular}{|l|l|c|c|l|}
\hline $\begin{array}{c}\text { Independent } \\
\text { Variable }\end{array}$ & $\begin{array}{c}\text { Dependent } \\
\text { variable }\end{array}$ & $\begin{array}{c}\text { Path } \\
\text { Coefficient }\end{array}$ & p-value & Explanation \\
\hline Leadership style $\left(\mathrm{X}_{1}\right)$ & Motivation $\left(\mathrm{Y}_{1}\right)$ & 0.547 & 0.002 & Significant \\
\hline Leadership style $\left(\mathrm{X}_{1}\right)$ & Prosperity $\left(\mathrm{Y}_{2}\right)$ & 0.158 & 0.342 & $\begin{array}{l}\text { Non } \\
\text { Significant }\end{array}$ \\
\hline Leadership style $\left(\mathrm{X}_{1}\right)$ & Performance $\left(\mathrm{Y}_{3}\right)$ & 0.456 & 0.013 & Significant \\
\hline Motivation $\left(\mathrm{Y}_{1}\right)$ & Prosperity $\left(\mathrm{Y}_{2}\right)$ & 0.513 & 0.009 & Significant \\
\hline Motivation $\quad\left(\mathrm{Y}_{1}\right)$ & Performance $\left(\mathrm{Y}_{3}\right)$ & 0.022 & 0.909 & $\begin{array}{l}\text { Non } \\
\text { Significant }\end{array}$ \\
\hline Prosperity $\left(\mathrm{Y}_{2}\right)$ & Performance $\left(\mathrm{Y}_{3}\right)$ & 0.362 & 0.046 & Significant \\
\hline
\end{tabular}

Research Result 2012.

Table 2 Indirect Effect Hypothesis Testing Results

\begin{tabular}{|l|l|c|c|c|}
\hline $\begin{array}{c}\text { Independent } \\
\text { Variable }\end{array}$ & Variable mediating & $\begin{array}{c}\text { Dependent } \\
\text { variable }\end{array}$ & $\begin{array}{c}\text { Path } \\
\text { Coefficient }\end{array}$ & Explanation \\
\hline Leadership style $\left(\mathrm{X}_{1}\right)$ & Motivation $\left(\mathrm{Y}_{1}\right)$ & Prosperity $\left(\mathrm{Y}_{2}\right)$ & 0.281 & Significant \\
\hline Leadership style $\left(\mathrm{X}_{1}\right)$ & Motivation $\left(\mathrm{Y}_{1}\right)$ & Performance $\left(\mathrm{Y}_{3}\right)$ & 0.012 & Non Significant \\
\hline Leadership style $\left(\mathrm{X}_{1}\right)$ & Prosperity $\left(\mathrm{Y}_{2}\right)$ & Performance $\left(\mathrm{Y}_{3}\right)$ & 0.057 & Non Significant \\
\hline Motivation $\left(\mathrm{Y}_{1}\right)$ & Prosperity $\left(\mathrm{Y}_{2}\right)$ & Performance $\left(\mathrm{Y}_{3}\right)$ & 0.186 & Significant \\
\hline
\end{tabular}

Research Result 2012.

The results of hypothesis testing of direct influence pathways can also be seen in the image path diagram like Figure 3.1 as follows:

Ficture 3.1

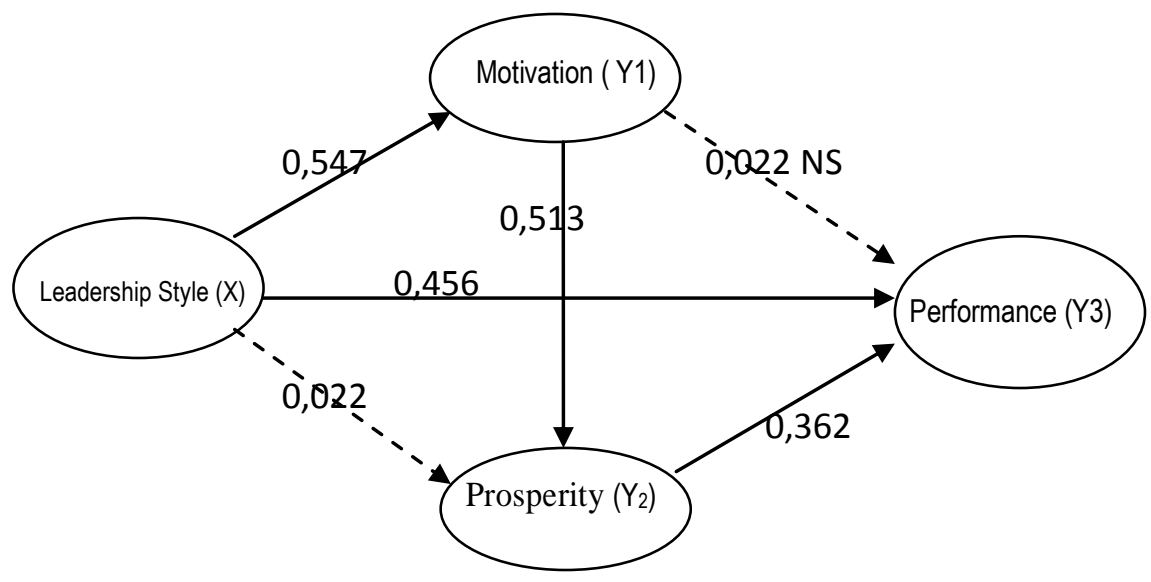


Explanation : Significant Not Significant

\section{Effect of Leadership Style on motivation}

\section{Analysis And Discussion}

The results of research that leadership style is significantly influence on the motivation. The highest indicator in building leadership style is the carrying capacity. The village chief thinks that Bekasi regent leadership style has generated motivation in implementing performance. This indicates that the leadership style of level II Bekasi area has a lot of motivation to work well against subordinates (village chief). This leadership style which leads to the implementation of transformational always puts the motivation to subordinates. This research together with research of Liu, Caroline H, 2007, stating that leadership style significantly influence work motivation.

\section{The effect of leadership style to prosperity}

The research results showed that leadership style had no effect on prosperity. The highest indicator in building prosperity was the deciding factor. The village chief determines that perceived synergies with transformational leadership style. This indicates that the style of leadership has not been able to empower the village headman had been given the heads do not get a salary from the government. These results support Sundong research, 2001 which states that leadership style had no effect on prosperity.

\section{The influence of leadership style on the village chief performance.}

The highest indicators in building village chief performance were Social Insurance / Social Security. This result proves that the style of leadership of Bekasi second level regency district was able to build leadership so that they can directly affect the performance of the village chief. These results are similar to Locander result, (2002), and Bono, JE \& FY Judge (2003) which states that leadership style directly affects the performance.

\section{The effect of motivation on the village chief performance.}

The highest indicator in building motivation is intensity results prove that motivation does not affect the performance of the village head. This indicates that the motivation that was built by the District Head II Bekasi, has not been able to affect the performance of the village head. These results do not support the findings of Pillai, 1999, which states that the motivation significant positive effect on individual performance.

\section{Prosperity influence to village chief performance.}

These results prove that prosperity has significant effect on the village chief performance. These results indicate that prosperity is built through the potential of the village chiefs so ttha it could improve performance.

\section{The Effect of Motivation on prosperity.}

The results prove that motivation could affect prosperity. These results indicate that personality motivation built through the village head to further enhance the performance of the village head and the nongovernmental organizations.

\section{References}

[1] Pillai, R., Schriesheim, C. S., \& Williams, E. S. (1999). Fairness perceptions and trust as mediators for transformational and transactional leadership: A two-sample study. Journal of Management, 25, 897-933.

[2] Podsakoff, P. M., MacKenzie, S. B., \& Bommer, W. H. (1996). Transformational leader behaviors and substitutes for leadership as determinants of employee satisfaction, commitment, trust, and organizational citizenship behavior. Journal of Management, $22,259-298$.

[3] Liu, Caroline H, 2007, Transactional Transformational, Transcendental Leadership : Motivation Effectiveness And Measurement Of Transcendental Leadership, Leading The Future of the Public Sector, May 31- June 2 hal.1-25.

[4] Ozalli, 2003, Effect of Transformational leadership on empowerment and team effectiveness, Leadership \&Organizational Development Journal

[5] Avolio, B., Luthans, F., \& Walumbwa, F.O., (2004). Authentic leadership: Theory-building for veritable sustained performance. Working paper. Gallup Leadership Institute, University of Nebraska, Lincoln.

[6] Bass, Avolio, Jung \& Berson, 2003, Predicting Unit Performance By Assessing Transformational And Transactional, Journal Applied Psychology.

[7] Ogbonna, E. \& L.C. Harris (2000), "Leadership style, organizational culture and perfromance: Empirical evidence from UK companies", International Journal of Human Resource Management, Vol. 11, No. 4, pp. 766-788

[8] Locander, W.B., F. Hamilton, D. Ladik \& J. Stuart (2002), "developing a leadership-rich culture: The missing link to creating a market-focused organization, Journal of Market-Focused Management, Vol. 5, pp. 149-163 
[9] Bono, J.E. \& T.A. Judge (2003). "Self-concordance at work: Toward understanding the motivational effects of transformational leaders", Academy of Management Journal, Vol. 46, No. 5, pp. 554-571

[10] Linjuan Rita Men, 2010, Measuring the impact of Leadership Style and Employee Empowerment on Perceived Organizational Reputation. Dissertation Scholl of Communication University of Miami.

[11] Sundong, Ahn, Joong-Ho and Kwon, "The Effect of CIO's Transformational Leadership on Empowerment and Leadership Performance: An Analysis Using Structural Equation Modeling" (2001). PACIS 2001 Proceedings. Paper 56.

[12] Yukl, 1989, Managerial Leadership: A review Theory and research, Yearly Review of Management.

[13] Kreitner, R., dan Kinicki, A. 2005. Organizational Behavior Jakarta: Salemba

[14] Zhu, W., Riggio, R., Avolio, B. J., \& Sosik, J. J. (2011). The effect of leadership on follower moral identity: Does transformational/transactional style make a difference? Journal of Leadership and Organizational Studies, $18(2), 150-163$.

[15] Gibson, James, L., John, M. Ivancepich, James, H., D. Jr. (1996). Organization and Process Structure Behavior Management. Translator: Nunuk Andriani, Jakarta: Bina Putra

[16] Daft, R. L. (2005). The Leadership Experiences (3rd). South-Western : Thomson

[17] Robbins, S.P., 1996, Organizational Behavior, Prentice Hall, New York. [18]Baron, R.A. and Greenberg, J., 1998, Behavior in Organization : Understanding and Managing the Human Side of Work, Allyn and Bacon, New York.

[19] Spreitzer, 1997, Toward a common ground in defining empowerment, Research in Organizational Change and Development

[20] Byars dan Rue, Managing Human Resources: Productivity, Quality Work of Life, Profit. Fourth Edition, McGraw-Hill Inc, New York, 1995.

[21] Fenwick, F. J. \& Gayle, C. A. (2008). Missing Links in Understanding the Relationship between Leadership and Organizational Performance. International Business \& Economics Research Journal, Volume 7.

[22] Judge, T. A. and Ilies, R. (2002). Relationship of Personality to Performance Motivation: A meta-analytic review. Journal of Applied Psychology, 87(4): 797-807.

[23] Keller, R. T. (2006). Transformational Leadership, Initiating Structure Substitutes for Leadership: A Longitudinal Study of Research \& Development Project Team Performance. Journal of Applied Psychology, 91(1): 202-210.

[24] Drucker, Peter R., (1977) Management Task, Responsibilities, Newyork:Harper and Row.

[25] Hair, Jr., and Joseph F., Multivariate Data Analysis, Prentice Hall International, New Jersey, 1998. 